\title{
Survey of mushroom consumption and the possible use of gamma irradiation for sterilization of compost for its cultivation in Southern Ghana
}

Nii Korley Kortei ${ }^{1 *}$, George Tawia Odamtten ${ }^{2}$, Mary Obodai ${ }^{3}$, Michael Wiafe-Kwagyan ${ }^{2}$ and Juanita Prempeh ${ }^{4}$

\begin{abstract}
Background: Mushroom cultivation is increasingly becoming a serious agribusiness in Ghana, especially at the time when entrepreneurship is being encouraged to reduce the pressure of employment in the government sector and also due to its nutritional and medicinal attributes.

Methods: A survey was carried out using the rapid appraisal method to review the existing methods of sterilization, use of gamma radiation in substrate sterilization and food preservation, preference of mushrooms in Ghana by consumers and nutritional and medicinal attributes of the mushroom.

Results: The survey demonstrated the popularity of drum (moist heat) technique of sterilization in Ghana. Majority (64\%) of the respondents were dissatisfied with the method of sterilization of compost and spawn substrate, while $36 \%$ indicated the method was alright by them. Majority (82\%) of the respondents had never heard of sterilization of substrates for cultivation and its subsequent preservation of food or mushroom by gamma irradiation technique. All consumers (100\%) desired to see their favorite mushroom produced all year round, and this constituted a significant $(p<0.05)$ viewpoint. Furthermore, a significant $(p<0.05)$ majority $(90 \%)$ of the respondents were all for promotion of the consumption of mushroom, while a small percentage (10\%) were noncommittal.
\end{abstract}

Conclusion: Information and knowledge on the gamma irradiation technique for substrate production and consumption patterns of P.ostreatus mushrooms were not widely disseminated as anticipated.

Keywords: Moist heat, Gamma radiation, Compost, Mushroom, Survey, Ghana, Consumption

\section{Background}

Mushroom cultivation has become a profitable commercial agribusiness in many developing and developed countries such as the USA, Great Britain, China, Asia, Japan and Europe. Many indigenous and commercial cultivation methods have been employed over the years to domesticate many species of edible mushrooms for human consumption [1]. Fungi in the Basidiomycota are large and diverse which include forms commonly known

\footnotetext{
*Correspondence: nkkortei@uhas.edu.gh

${ }^{1}$ Department of Nutrition and Dietetics, School of Allied Health Sciences,

University of Health and Allied Sciences, PMB 31, Ho, Ghana

Full list of author information is available at the end of the article
}

as mushrooms, boletes, earthstars, stinkhorns, bird nest fungi, jelly fungi, bracket or shelf fungi and rusts and smuts [2]. The mushrooms are sought eagerly for human consumption. Consequently, the medical community widely recognizes the health-stimulating properties of mushrooms [3].

Mushroom cultivation as an agribusiness has gained some modest success in Ghana because many of our forest reserves which support rich wild growth of the mushrooms are depleting fast in rich biodiversity of indigenous mushroom species. It has now become necessary to adopt modern mushroom cultivation strategies to sustain supplies of the species for human consumption in Ghana such as those obtained in the developed economies. 
The evolution of technical knowledge for commercial cultivation of mushrooms was a product of human need to extend the period of availability (seasonality) and reduce the inherent risk of mushroom hunting, thus meeting the growing demands for diverse culinary mushrooms [4]. Some modern pretreatments of substrates for mushroom cultivation include the use of chemical amendments, steam and gamma irradiation.

Gamma radiations come from the spontaneous disintegration of radioactive nuclides (Cobalt 60 or Cesium $137)$ as their energy source. The high-energy gamma rays have high penetrating power and pass through any matter without leaving any radioactivity within the product. The deep penetrating power of gamma rays could serve as a decontamination agent of food items [5]. Currently, over 34 countries are using gamma irradiation for this purpose [5]. The gamma rays can also be used as a hydrolytic agent due to its unique ability to enhance depolymerization of lignocellulose linkages without the need to aid exogenous toxic chemicals [6-9].

Recent studies in Ghana have demonstrated the ability of gamma radiation to depolymerize lignocellulosic mushroom compost into inexpensive protein per unit area of mushroom of the genus Pleurotus [10-14] and produced quantities of the cherished mushroom.

The use of this gamma irradiation technology to facilitate the cultivation of mushrooms on agricultural lignocellulose in Ghana promises to be faster and a more reliable technique to reduce the humdrum tasks associated within the existing conventional production chain [10-14]. The objective of this paper was to assess the knowledge of the respondents to a questionnaire on the benefits of mushroom consumption and the possibility of the use of gamma radiation sterilization of substrates and spawns for mushroom cultivation.

\section{Materials and methods}

\section{Sample area for questionnaire administration}

The study areas chosen for the collection of data were Greater Accra, Central and Eastern regions where majority of the producers and consumers of mushrooms are located. Accra is the capital city of Ghana, and it is in close proximity with the Eastern and Central regions. Majority of the studies were conducted in Accra because the national irradiation facility is located at the Ghana Atomic Energy Commission (GAEC) at Kwabenya which was used for this study. Data from mushroom cultivators were collected from mushroom farms in the above mentioned regions of Ghana. Questionnaires were administered to obtain information on method of sterilization, aspect of production which needs much attention, general perception about production, popularity of gamma irradiation technique, etc. A total of 150 volunteers were interviewed.

Consumers were interviewed from the following locations: Ofankor, Adenta-Frafraha, Cape Coast Polytechnic, Somanya, Nkawkaw, CSIR-FRI, Shiashie, Graduate School of Nuclear and Allied Sciences, Kwabenya, University of Ghana, Abelemkpe and Dome market, etc. (Greater Accra, Eastern and Central regions of Ghana) (Fig. 1). Questionnaires were administered to obtain information on the benefits of consumption of mushrooms, methods of preservation, qualities looked out for in mushrooms localities where mushrooms were obtained, etc. A total of 120 volunteers were interviewed. The cultivators of mushroom were selected from the members of the Mushroom Growers' Association of Ghana found in the selected regions.

\section{Study design}

Convenient cross-sectional sampling method was used.

\section{Statistical analysis}

Graphical presentations of data were done with Excel for Microsoft windows (version 10). Descriptive statistics were employed with SPSS 16 (Chicago, USA). Parameters investigated were subjected to analyses of variance (one-way ANOVA) at significant difference $(p<0.05)$.

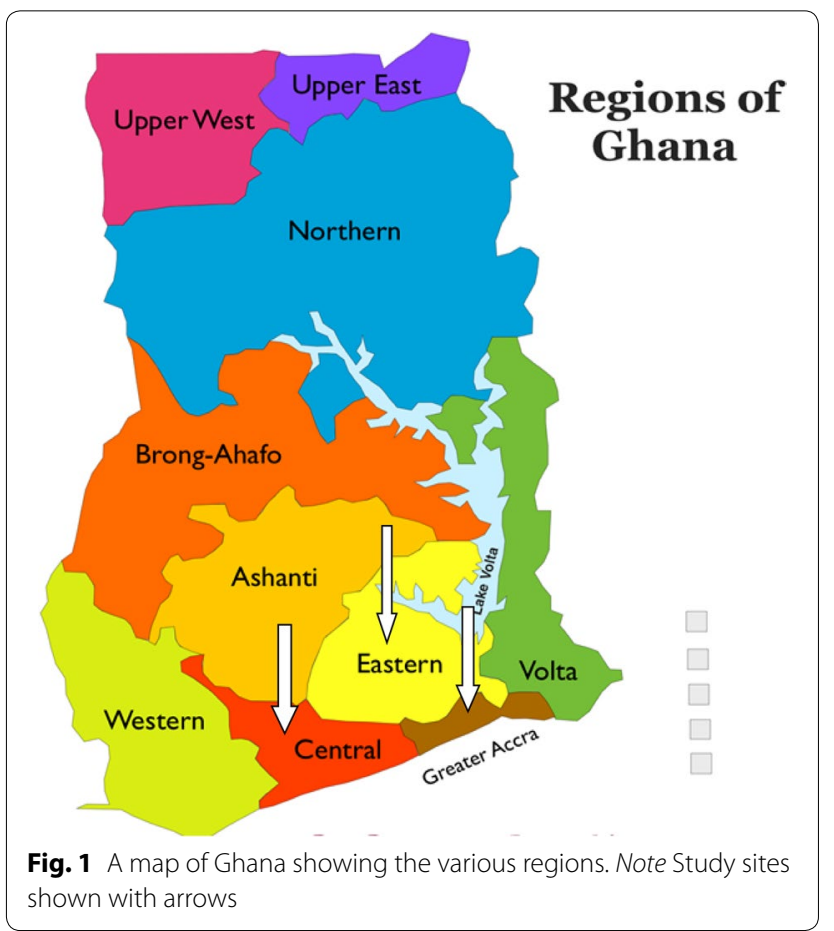




\section{Results}

\section{Producers}

Majority of the respondents (70\%) use drum pasteurization (moist heat), while $26 \%$ treat the substrate with unspecified chemicals. The remaining $4 \%$ use other unspecified methods of sterilization (Fig. 2). Majority of the respondents (64\%) were not satisfied with the sterilization methods; $36 \%$ were in agreement with the sterilization procedure. The differences observed were significant $(p<0.05)$ (Fig. 3$)$.

A significant $(p<0.05)$ majority of $82 \%$ have not heard of the sterilization of mushroom compost by gamma irradiation. The remaining $18 \%$ were aware of its use in sterilization of compost before spawning (Fig. 4). The survey also showed that $34 \%$ of the respondents believe that the sterilization process needs more attention in mushroom cultivation industry, while $50 \%$ desired the inoculation process to be perfected to exclude contaminants (Fig. 5). About 8\% wanted more attention to be paid to packaging. The rest were noncommittal. Majority (92\%) of mushroom cultivators agreed to the need to achieve better sterilization of compost bags and other ancillary methods, while an insignificant $(p>0.05)$ minority of the cultivators disagreed (Fig. 6).

Because fresh mushrooms are perishable, shelf-life extension is vital to the industry. Exactly $54 \%$ of the respondents were able to preserve all their produce, while $46 \%$ were unable to preserve all their produce (Fig. 7).

\section{Consumers}

Majority of consumers interviewed (72\%) intimated that they prefer eating oyster mushrooms (Pleurotus spp.), while $20 \%$ patronized the termite mushroom (Termitomyces spp.) (Fig. 8). Domo (Volvariella volvacea) or the oil palm mushroom was least patronized (8\%). All consumers (100\%) would like to see their favorite mushroom

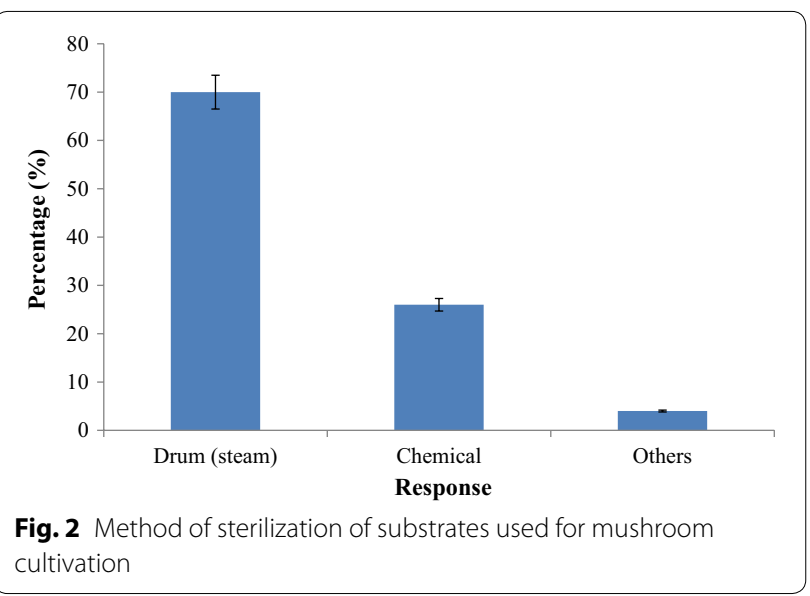

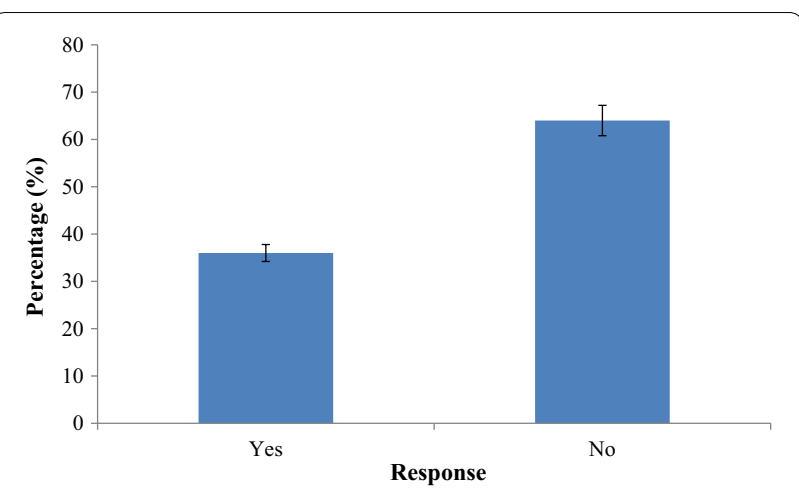

Fig. 3 Mushroom farmer's satisfaction on the reliability of their sterilization methods in mushroom production

produced all year round, and this constituted a significant $(p<0.05)$ viewpoint (Fig. 9). Furthermore, a significant $(p<0.05)$ majority $(90 \%)$ of the respondents were all for promotion of the consumption of mushroom (Fig. 10), while a small percentage (10\%) were noncommittal.

On the question of the medicinal and nutritional benefits derived from eating mushrooms, 54\% stated that mushrooms have medicinal values; $34 \%$ agreed mushrooms have nutritional attributes not excepting $10 \%$ who assigned other unspecified benefits of eating mushrooms. The remaining $2 \%$ said that mushrooms have both medicinal and nutritional values (Fig. 11). It was shown by the survey that majority (64\%) of mushroom consumers obtained them directly from the market place. Interestingly, 34\% obtained their supply from backyard garden or from the farm (Fig. 12) and the remaining 2\% harvested from the wild in the mushroom season.

The aesthetic appearance of mushrooms contributed to the choice of mushroom for consumption; $34 \%$ of the consumers considered appearance as important and $30 \%$ considered the taste as a determining factor, while

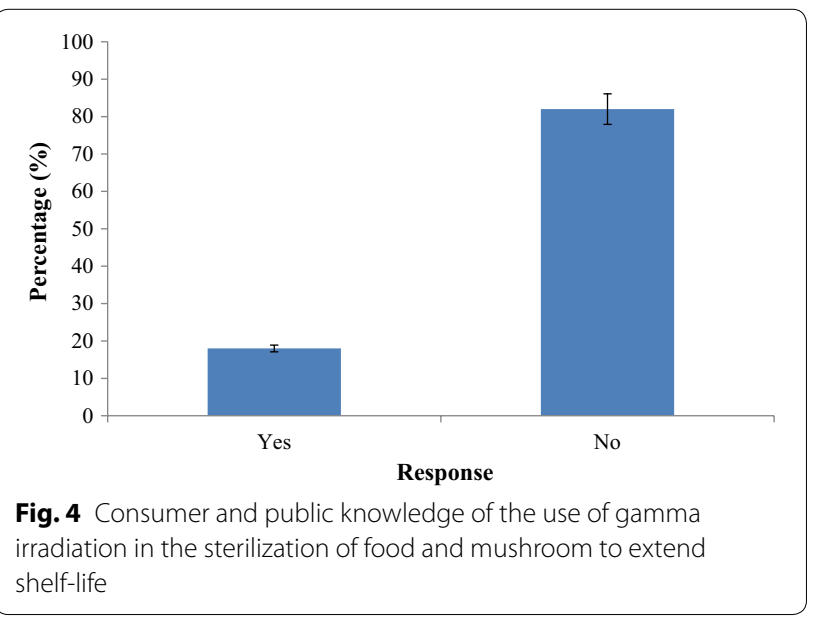




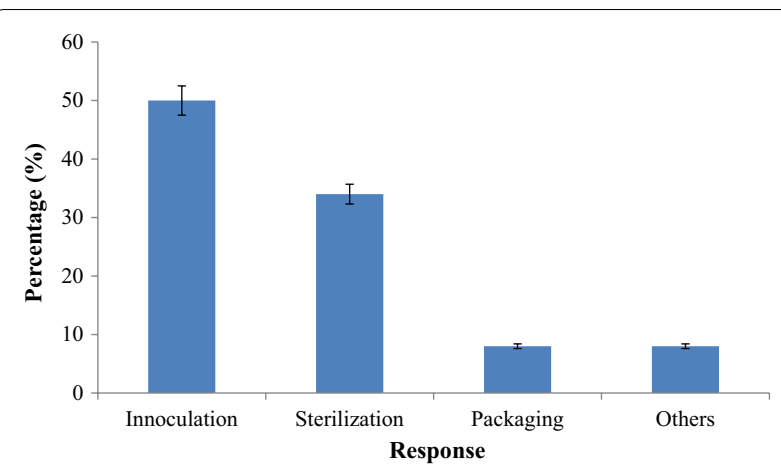

Fig. 5 Aspects of production which needs much attention according to respondents

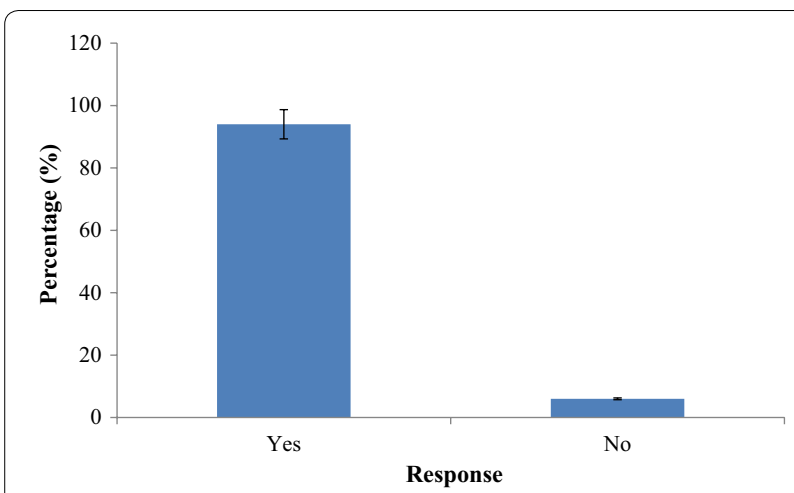

Fig. 6 Response of mushroom cultivators on the need to achieve better sterilization of compost and other ancillary methods used in the production of mushrooms

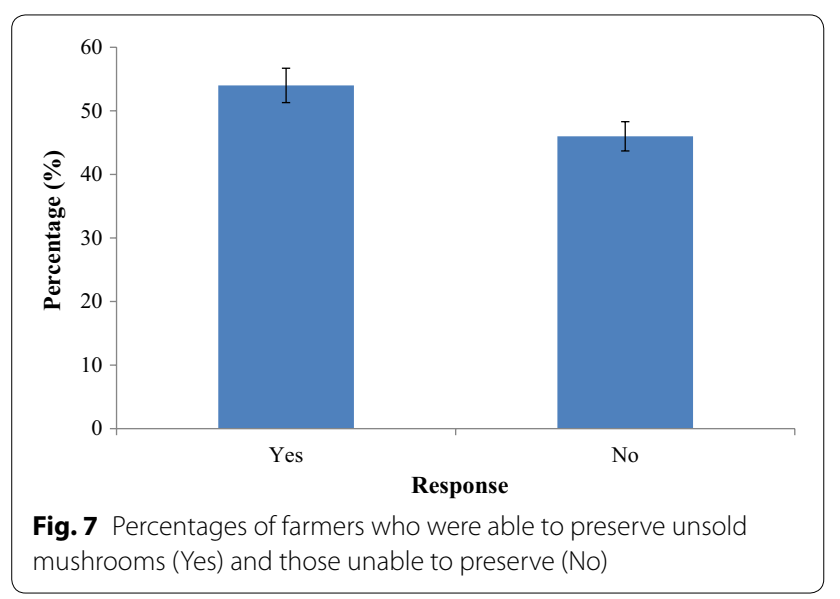

$12 \%$ considered both texture and taste as equally important. Only, $10 \%$ used texture as a criterion for choosing mushroom and $6 \%$ considered both texture and appearance concurrently before choosing a mushroom for purchase (Fig. 13). Currently in the country, mushrooms are

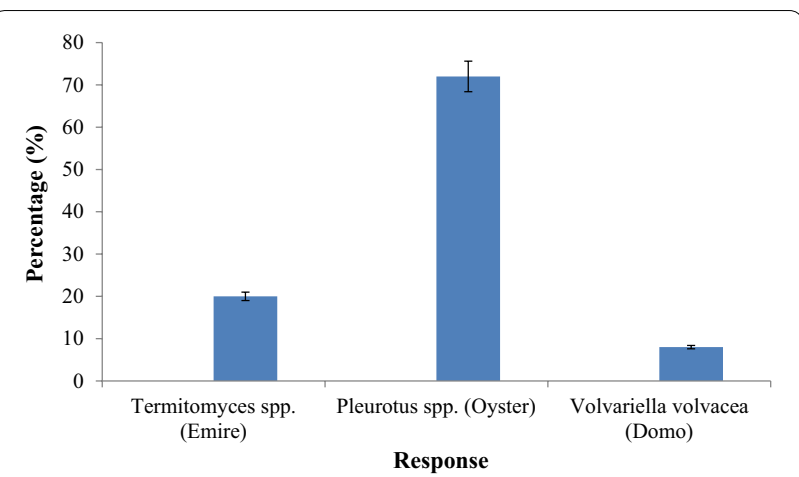

Fig. 8 Types of mushrooms most patronized by consumers

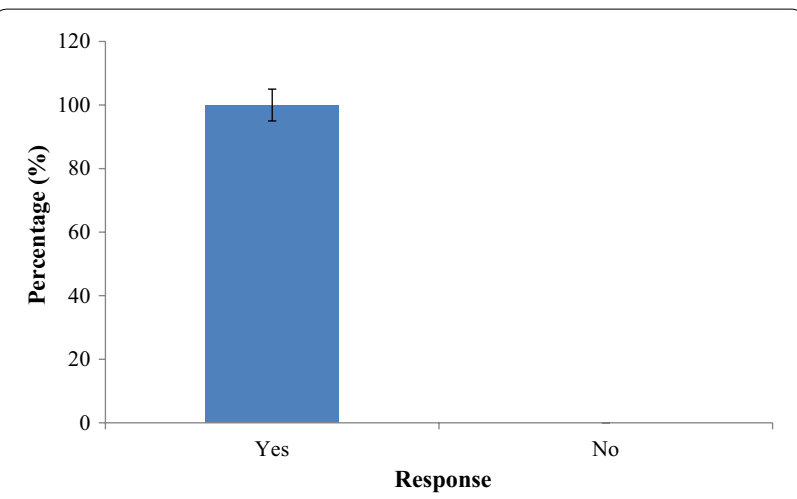

Fig. 9 Consumer preference to see their favorite mushroom produced throughout the year

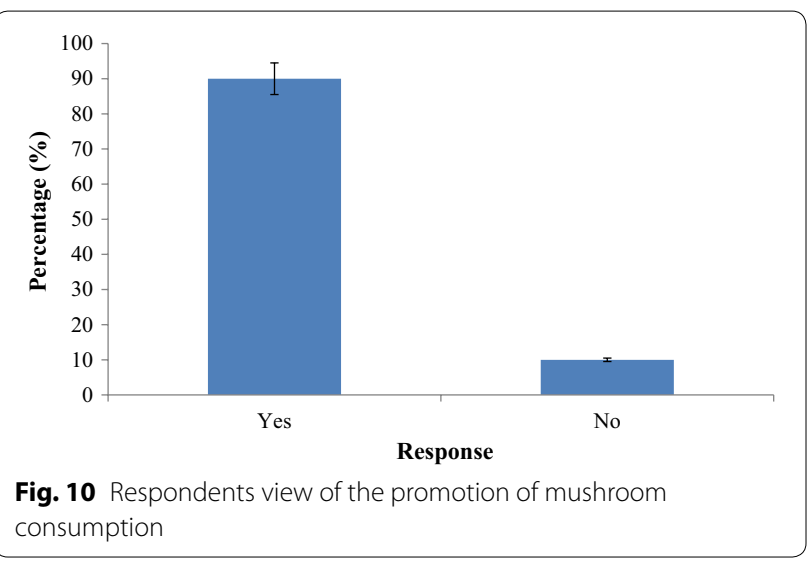

preserved by drying by $55 \%$ of the people, while $32 \%$ use refrigerators for preservation. The rest preserve mushrooms by smoking after blanching in brine (Fig. 14). Exactly $45 \%$ of the respondents stated that mushroom production was laborious, while $10 \%$ believed the process was expensive. About $45 \%$ found the process and costing normal (Fig. 15). 


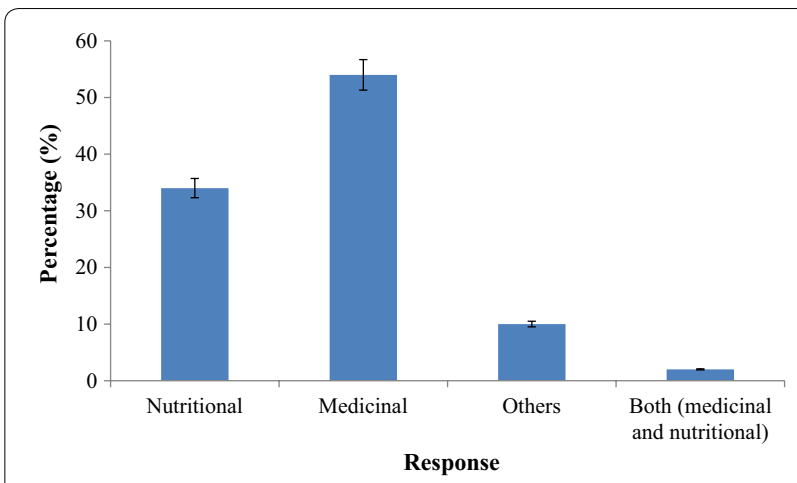

Fig. 11 Respondents view on the benefits of eating mushrooms

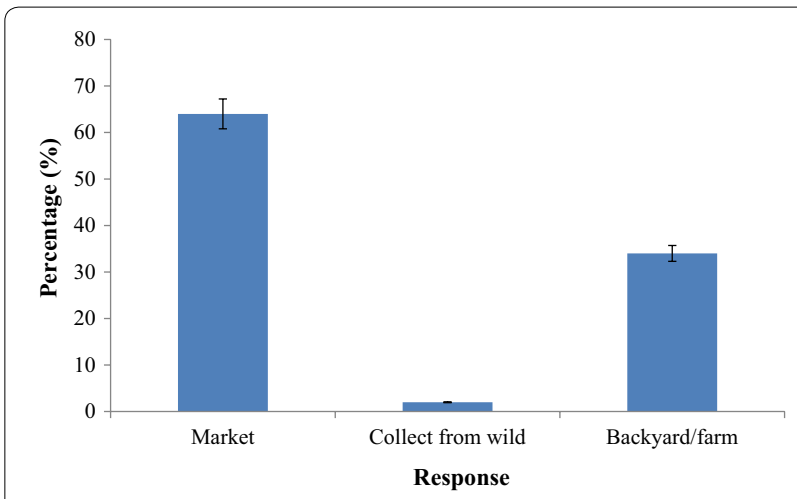

Fig. 12 Source of mushrooms for use by consumers

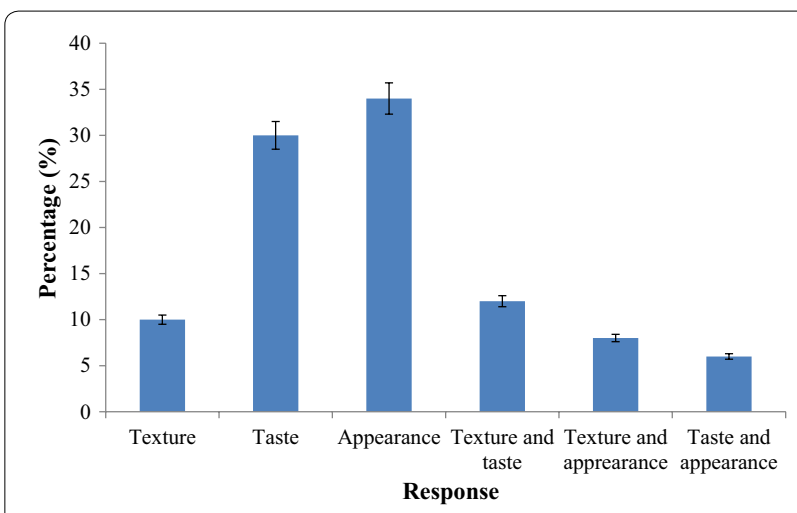

Fig. 13 Choice of mushroom for consumption by consumers based on the listed criteria

\section{Discussion}

Results obtained from the structured questionnaire survey (Fig. 2) demonstrated the popularity of drum (moist heat) technique of sterilization both locally and internationally which agrees with findings by several researchers $[9,10,15,16]$. Majority $(60 \%)$ of the respondents were

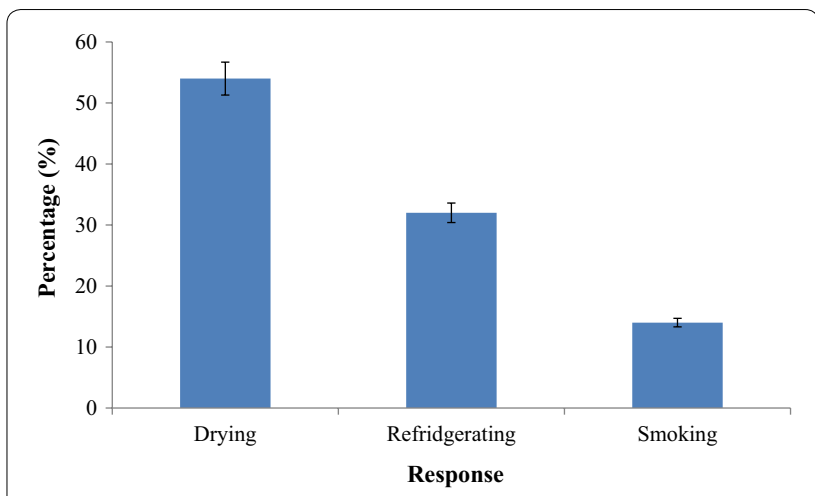

Fig. 14 What are the methods used to preserve mushrooms?

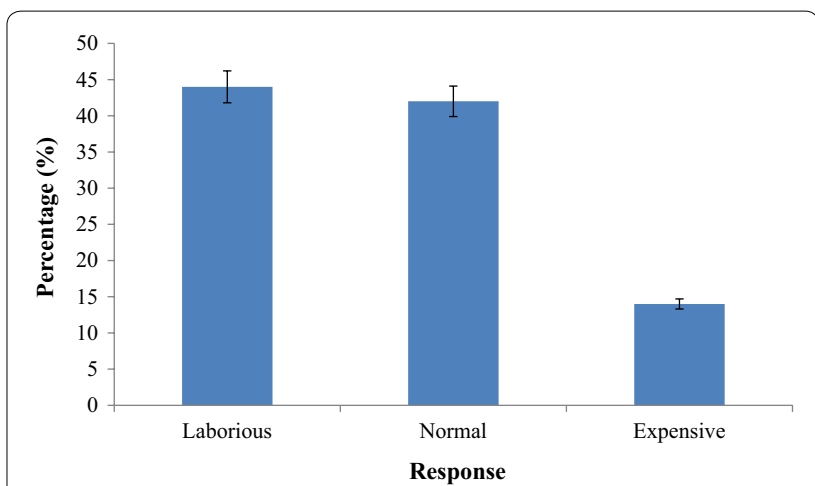

Fig. 15 Public opinion on labor and cost of mushroom production in Ghana

not satisfied with their method of sterilization of compost, while $30 \%$ found it alright (Fig. 3).

This also gave an indication of general unsatisfactory results obtained from their sterilization methods and therefore their desire to improve upon the improper or incomplete sterilization resulting in partial or incomplete elimination of contaminants. Residual contaminants from incomplete pasteurization of compost and spawn substrates could result in reduction in economic yield of mushrooms on compost substrates due to antibiosis and competition for nutrients.

Interestingly, majority of the respondents (82\%) have not heard about sterilization of mushroom compost using gamma irradiation (Fig. 4) although gamma irradiation sterilizing technique has now gained some credence among mushroom farmers in Ghana. In spite of this, some researchers $[6,8,9,11-14]$ have reported success in the use of gamma radiation to decontaminate and depolymerize different lignocellulosics agrowastes for P.ostreatus cultivation, thus achieving growth and good of fruiting bodies yield comparable to the moist heat (drum) technique. Gamma irradiation facility technique allows a greater volume and quantity of sterilized 
compost bags per unit time, and is less laborious and more effective decontamination of substrate bags. This could probably reassure the majority of cultivators of mushrooms who expressed the need to achieve better sterilization technique for mushroom compost based on their experience with moist heat sterilization (Fig. 6).

Shelf-life extension of mushroom is economically vital to the industry. The most common method for the preservation of mushrooms is drying since it is the most economical and oldest method [17]. Data from this paper show that drying is the most popular preservation method of mushrooms in Ghana (Fig. 14). Several edible mushrooms are consumed by respondents, but the most preferred one was oyster mushrooms (Pleurotus spp.) (Fig. 8). Afetsu [18] reported similar results in a survey of mushroom consumption conducted in the Volta region of Ghana which agrees with the results obtained in this work. The popularity of mushroom to Ghanaian was shown in the survey where all respondents wanted an all year round supply (Fig. 9).

Obodai et al. [19] attributed oyster mushroom's emerging popularity among Ghanaians to its comparatively easy method of cultivation. This agrees with findings in this paper. However, results obtained in this paper (Fig. 8) contrast the findings of Apertorgbor et al. [20] who reported Termitomyces spp. as the most preferred mushrooms in the Eastern and middle belts of Ghana. Dijk et al. [21] made similar findings in South Cameroun where they very often consumed this mushroom. This difference in preference might be attributed to the availability of particular kinds of mushroom species, taste and/or medicinal attributes. Mushrooms have a myriad of benefits derived from its consumption. Mushrooms have been found to have some medicinal values [22]. The Asantes and Sefwis in Ghana believe that mushrooms lower blood pressure in hypertensive patients. The globular subterranean sclerotium of $P$. tuber-regium is chewed by local people to alleviate heart pains, and the powder is taken in warm water to lower blood pressure in hypertensive patients [23]. The medicinal value of mushrooms for Ghanaian consumers was evident from the questionnaire survey (Fig. 11). Completely colonized composted bags are readily available for sale at numerous mushroom farms and some research institutions such as the Council for Scientific and Industrial Research-Food Research Institute (CSIR-FRI) Ghana. With the current rate of deforestation caused by urbanization, bush fires and mining companies, the collection of wild mushrooms by the rural folk is greatly threatened leaving government-protected areas (forest reserves) as the only remaining areas where non-timber forest products can be collected [24].

The depletion of our forest is a major cause of scarcity of most mushroom species [20]. Rigorous scientific research into bioconversion of lignocellulosic waste by mushroom is making it possible to cultivate different species of mushrooms all year round with specific emphasis on Jun-Cao technology which involves the use of plastic bag and agro, industrial, forest lignocellulosic wastes. This practice is advantageous since it is more efficient and does not require so much space. Small-scale mushroom farms have emerged in Southern Ghana as a result of the introduction of the National Mushroom Development Project aimed at promoting the economic welfare of rural communities [23]. Mushroom production is a demand-driven enterprise and so requires the appropriate technologies to keep up with its supply. Consumers seem to prefer mushrooms on the basis of taste, appearance, texture or combination of these qualities (Fig. 13). Although production of oyster mushroom is laborious, it is also very capital intensive (Fig. 15).

\section{Conclusions}

The survey carried out showed among other things, the humdrum tasks of preparing the compost and spawn nutrient and the sterilization method, not excepting the short shelf-life of the harvested fruit bodies. Majority of the farmers were not aware of the possible use of gamma irradiation for the sterilization/pasteurization of the spawn nutrient and the 'wawa' sawdust compost as well as the preservation of both fresh and dry fruitbodies. However, consumers prefer to see their favorite mushroom on the market throughout the year.

\section{Abbreviations}

CSIR-FRI: Council for Scientific and Industrial Research-Food Research Institute; GAEC: Ghana Atomic Energy Commission; PMB: Private Mail bag; LG: Legon.

\section{Authors' contributions}

NKK, GTO and MO were involved in the conception of the research idea, design of the experiments, data analysis and also drafting of the paper. MW-K and JP participated in the design of the experiments and data collection. GTO and $\mathrm{MO}$ provided guidance and supervision of the entire research and critically reviewed the manuscript. NKK, GTO, MO and MW-K read, reviewed and amended manuscript. All authors read and approved the final manuscript.

\section{Author details \\ ${ }^{1}$ Department of Nutrition and Dietetics, School of Allied Health Sciences, University of Health and Allied Sciences, PMB 31, Ho, Ghana. ${ }^{2}$ Department of Plant and Environmental Biology, College of Basic and Applied Sciences, University of Ghana, P. O. Box LG 55, Legon, Ghana. ${ }^{3}$ Food Microbiology Divi- sion, Council for Scientific and Industrial Research-Food Research Institute, P. O. Box M20, Accra, Ghana. ${ }^{4}$ Department of Food Science, Royal Agricultural University, Cirencester, Gloucestershire GL7 6JS, UK.}

\section{Acknowledgements}

We are grateful to all the participants of this study and specifically acknowledge the technical assistance of our technical staffs at the University of Ghana, CSIR-FRI and the University of Health and Allied Sciences.

\section{Competing interests}

The authors declare that they have no competing interests. 


\section{Availability of supporting data}

The data sets used and analyzed during the current study are available to readers as in the manuscript.

\section{Consent for publication}

Not applicable.

Ethics approval and consent to participate

Not applicable.

\section{Funding}

Not applicable.

\section{Publisher's Note}

Springer Nature remains neutral with regard to jurisdictional claims in published maps and institutional affiliations.

Received: 30 Auqust 2018 Accepted: 7 November 2018 Published online: 13 November 2018

\section{References}

1. Stamets P. Growing gourmet and medicinal mushrooms. Olympia:Ten Speed Press and Mycomedia ${ }^{\mathrm{TM}}$; 1993. p. 55.

2. Pipenbring M. Introduction to Mycology in the Tropics. St. Paul Minnesota: American Phytopathological Society; 2015. p. 366.

3. Harpen GM. Healing mushrooms. Effective treatments for Todays illnesses. Garden City Park: Square One Publishers; 2007. p. 182.

4. Osarenkhoe OO, John OA, Theophilus DA. Ethnomycological conspectus of West African mushrooms: an awareness document. Adv Microbiol. 2014:4:39-64

5. IAEA-TECDOC-1530. Use of irradiation to ensure hygienic quality of fresh, pre-cut fruits and vegetables and other minimally processed food of plant origin. Proceedings of a final research coordination meeting organized by the joint FAO/IAEA Programme of Nuclear Techniques in Food and Agriculture, Pakistan. 2006.

6. Kortei NK, Wiafe-Kwagyan M. Evaluating the effect of gamma irradiation on eight different agro-lignocellulose waste materials for the production of oyster mushrooms (Pleurotus eous (Berk.) Sacc. Strain P-31). Croat J Food Technol Biotechnol Nutr. 2014;9(3-4):83-90.

7. Betiku E, Adetunji OA, Ojumu TV, Solomon BO. A comparative study of the hydrolysis of gamma irradiated lignocelluloses. Braz J Chem Eng. 2009;26(2):251-5.

8. Kortei NK, Odamtten GT, Obodai M, Wiafe-Kwagyan M, Dzomeku M. Comparative bioconversion of gamma irradiated and steam sterilized 'wawa' sawdust (Triplochiton scleroxylon) by mycelia of oyster mushroom (Pleurotus ostreatus) Jacq. Ex.Fr. Kummer. Int Food Res J. 2018;25(3):943-50.

9. Gbedemah C, Obodai M, Sawyer LC. Preliminary investigations into the bioconversion of gamma irradiated agricultural wastes by Pleurotus spp. Radiat Phys Chem. 1998;52(6):379-82.

10. Kortei JNK. Growing oyster mushrooms (Pleurotus ostreatus) on composted agrowastes: an efficient way of utilizing lignocellulosic materials. Germany: Lambert Academic Publishing; 2011. p. 9.
11. Kortei NK, Odamtten GT, Obodai M, Appiah V, Annan SNY, Acquah SA, Armah JNO. Comparative effect of gamma irradiation and steam sterilized composted 'wawa' (Scleroxylon triplochiton) sawdust sawdust on the growth and yield of Pleurotus ostreatus (Jacq.Ex.Fr.) Kummer. Innov Roman Food Biotechnol. 2014;14:69-78.

12. Kortei NK, Odamtten GT, Obodai M, Appiah V, Wiafe- Kwagyan M. Evaluating the effects of gamma irradiation and steam sterilization on the survival and growth of sawdust fungi in Ghana. Br Microbiol Res $J$. 2015;7(4):180-92.

13. Kortei NK, Odamtten GT, Obodai M, Appiah V, Adu-Gyamfi A. Wiafe Kwagyan M. Comparative occurrence of resident fungi on gamma irradiated and steam sterilized sorghum grains (Sorghum bicolor $L$ ) for spawn production in Ghana. British. Biotechnol J. 2015;7(1):21-32.

14. Kortei NK, Odamtten GT, Obodai M, Appiah V, Abbey L, Oduro-Yeboah $C$, Akonor PT. Influence of gamma radiation on some textural properties of fresh and dried oyster mushrooms (Pleurotus ostreatus)(Jacq. Ex. Fr) kummer. Ann Food Sci Technol. 2015;16(1):12-9.

15. Obodai M, Cleland- Okine J, Vowotor KA. Comparative study on the growth and yield of Pleurotus ostreatus mushroom on different lignocellulosic by-products. J Ind Microbiol Biotechnol. 2003;30:146-9.

16. Owusu-Boateng G, Dzogbefia VP. Establishing some parameters for the cultivation of oyster mushroom (Pleurotus ostreatus) on cocoa husk. J Ghana Sci Assoc. 2005;7(1):1-7.

17. Bala BK, Morshed MA, Rahman MF. Solar drying of mushroom using solar tunnel dryer. In: International solar food processing conference, 2009; $1-11$.

18. Afetsu JY. Postharvest losses in oyster mushroom (P. ostreatus) produced in the Ho Municipality of the Volta Region of Ghana. Msc. thesis, Kwame Nkrumah University of Science and Technology, Ghana. 2014.

19. Obodai M, Amoa- Awua W, Odamtten GT. Physical, chemical and fungal phenology associated with composting of 'wawa' sawdust (Triplochiton scleroxylon) used in the cultivation of oyster mushrooms in Ghana. Int Food Res J. 2010;17:229-37.

20. Apetorgbor MM, Apetorgbor AK, Nutakor E. Utilization and cultivation of edible mushrooms for rural livelihood in Southern Ghana. In: 17th Commonwealth Forestry Conference, Colombo, Srilanka. 2005.

21. van Dijk H, Onguene NA, Kuyper TW. Knowledge and utilization of edible mushrooms by local populations of the rain forest of South Cameroun. Ambio. 2003;32(1):19-23.

22. Singh VK, Patel Y, Naraian R. Medicinal properties of Pleurotus species (oyster mushrooms). World J Fungal Plant Biol. 2012;3(1):1-12.

23. Sawyerr LC. Genetic resource aspects of mushroom cultivation on small scale. In: Labarere JE, Menini UG (eds) Proceedings of the 1st international congress for the characterization, conservation, evaluation and utilization of mushroom genetic resources for food and agriculture. Bordeaux (France). 2000. pp. 193-199.

24. Meke G, Lowne J, Ngulabe M. Literature review of indigenous edible fungi from Miombo woodlands in Malawi. In: Boa E, Ngulube M, Meke G, Munthali C, Morris B (eds) Proceedings of forest regional workshop on sustainable use of forest products. Miombo wild edible fungi. 1987. Common mushrooms of Malawi. Fungiflora. Oslo, Norway. 2000. p 108.

Ready to submit your research? Choose BMC and benefit from:

- fast, convenient online submission

- thorough peer review by experienced researchers in your field

- rapid publication on acceptance

- support for research data, including large and complex data types

- gold Open Access which fosters wider collaboration and increased citations

- maximum visibility for your research: over $100 \mathrm{M}$ website views per year

At BMC, research is always in progress.

Learn more biomedcentral.com/submissions 